\title{
A REVIEW OF PHYTOCHEMICAL PROPERTIES, ANTIBACTERIAL ACTIVITY, AND TOXICITY STUDY OF Averrhoa bilimbi LEAVES AND FRUIT
}

\author{
Intan Safitri ${ }^{1}$, Ni Putu Eka Leliqia ${ }^{{ }^{*}}$ \\ ${ }^{1}$ Pharmacy Department, Faculty of Mathematics and Natural Sciences, Udayana University, \\ Indonesia
}

Corresponding author email: eka_leliqia@unud.ac.id

\begin{abstract}
Background: Averrhoa bilimbi or starfruit is a plant that is commonly found in Indonesia. A. bilimbi is widely used as herbal therapy against various diseases, especially those caused by bacteria. Objective: This article is intended to provide information regarding the chemical content of $A$. bilimbi, its antibacterial potential, and its safety level. Methods: The preparation of this article used a systematic literature review method of articles that have been published in both national and international scientific journal. Result: Leave and fruit of $A$. bilimbi is known to contain several classes of primary and secondary metabolites, namely carbohydrates, proteins, fats, flavonoids, alkaloids, glycosides, saponins, tannins, triterpenoids, and steroids. A. bilimbi also contains several macros and micro minerals including calcium $(\mathrm{Ca})$, magnesium $(\mathrm{Mg})$, and zinc $(\mathrm{Zn})$. A. bilimbi could inhibit the growth of various Gram positive and negative bacteria which have been proven through in vitro testing with diffusion and dilution methods. Based on the acute toxicity study, it was found that $80 \%$ ethanol extract of $A$. bilimbi fruit had an $\mathrm{LD}_{50}$ value of above $5.000 \mathrm{mg} / \mathrm{kg} \mathrm{BW}$ so that it is practically non-toxic. Based on sub-chronic toxicity of A. bilimbi up to a dose of $500 \mathrm{mg} / \mathrm{kg}$ BW there was no death in the test animals and shows a toxic effect. Conclusion: The leaves and fruit of A. bilimbi have antibacterial activities. The compounds contained in A. bilimbi are thought to have a role in its antibacterial activity. Based on several toxicity studies, the ethanol extract of A. bilimbi has been proven safe to use.
\end{abstract}

Keywords: Averrhoa bilimbi, Starfruit, Antibacterial, Chemical Properties, Toxicity.

\section{INTRODUCTION}

Averrhoa bilimbi or more commonly known as starfruit is a plant of the Oxalidaceae family that originates from Southeast Asia and is widely cultivated or found throughout Sri Lanka, Indonesia, the Philippines, Bangladesh, Malaysia, Myanmar, and Zanzibar ${ }^{[1,2]}$. However, in Indonesia, the use of $A$. bilimbi is still not optimal considering its various properties and abundant existence. Based on its morphology, A. bilimbi leaves have alternate arrangement, pinnate, and ovate to oblong shape. Fruit is obovoid or ellipsoid shape, measuring $5.5-7 \mathrm{~cm}$ long ${ }^{[3]}$. Traditionally $A$. bilimbi is used for the treatment of thrush, cough, acne, tinea versicolor, and digestive dysfunction ${ }^{[4]}$. Based on its empirical benefits, there have been many studies related to the antibacterial effects of $A$. bilimbi.

Research on the antibacterial effect of herbal ingredients has been developed due to the increasing incidence of bacterial resistance. Bacterial resistance to certain 
antibiotics is a global problem faced by both developed and developing countries due to the irrational use of antibiotics so that many efforts have been made to overcome this problem. One of the efforts made is the discovery of new drugs from herbal plants that have the potential to act as antibiotics $[5,6]$.

Based on the research, the leaves and fruit of A. bilimbi have been shown to have antibacterial activities. The activities cannot be separated from a chemical compound that plays an active role as an antibacterial agent such as flavonoids, tannins, glucosides, formic acid, citric acid, and several minerals such as calcium and potassium $^{[7,8]}$. Therefore, this article review is expected to provide information about the chemical compounds contained in $A$. bilimbi, its potential as an antibacterial, and its safety level based on toxicity study.

\section{METHODS}

The method used in compiling this article is a systematic literature review. Articles were collected both published in national and international scientific journals online from Google scholar and Scopus portal. Literature was original article with testing phytochemical content, antibacterial activity, and toxicity tests on Averrhoa bilimbi.

\section{RESULTS AND DISCUSSION}

This section discusses the results of research related to the phytochemical content of A. bilimbi, its antibacterial activity which has been tested through the diffusion method where the observed parameters are the inhibition diameter and the dilution method where the observed parameters are the MIC and MBC values. Besides, the results of acute and subchronic toxicity tests on tested animals, as well as the brine shrimp lethality test (BSLT) toxicity test on shrimp larvae were also explained.

\section{Phytochemical Content Averrhoa bilimbi}

Averrhoa bilimbi is known to contain primary metabolites and secondary metabolites. The $70 \%$ ethanol extract of $A$. bilimbi leaves qualitatively contains several groups of chemical compounds namely alkaloids, saponins, tannins, phenolic, flavonoids, triterpenoids, steroid, and glycosides $^{[9]}$. In addition, $70 \%$ ethanol extract of $A$. bilimbi fruit also contains carbohydrates, protein, fat, vitamin A, vitamin $C$, and vitamin $E^{[10]}$. The results of phytochemical screening from the water extract of $A$. bilimbi fruit showed that the content of several groups of chemical compounds such as carbohydrates, proteins, flavonoids, tannins, and hydrolyzed tannins. The chloroform extract of $A$. bilimbi fruit contains tannins and flavonoids. Meanwhile, the methanol extract of $A$. bilimbi fruit contains protein and flavonoids. Further identification of the methanol extract of the fruit of A. bilimbi with methods Thin Layer Chromatography (TLC) showed that the extract contains compounds bitter, volatile oil, valeopotrait, coumarin, flavonoids, and terpenes ${ }^{[11]}$. A. bilimbi fruit is also rich in macro and micro mineral content. Macro-minerals contained in A.bilimbi fruit are calcium $(\mathrm{Ca})$, magnesium $(\mathrm{Mg})$, phosphorus $(\mathrm{P})$, potassium $(\mathrm{K})$, and sodium $(\mathrm{Na})$. Meanwhile, the micro minerals contained in A.bilimbi are zinc ( $\mathrm{Zn})$, iron (Fe), copper $(\mathrm{Cu})$, and manganese $(\mathrm{Mn})^{[12]}$.

A study conducted by Auw et al. (2014), identified 15 compounds, 3 of which were new compounds from the ethanol extract of $70 \%$ A. bilimbi leaves. The twelve known compounds are $\beta$ amyrin, $\beta$-amyrenone, $\beta$-sitosterol, phytol, aurantiamide benzoate, stigmastanol, 4hydroxycinnamic acid, trans-cinnamic acid, (S)-dehydrovomifoliol, (6S,7aR)-loliolide, phloretic acid, and carambolaflavone.The three new known compounds are 7-Omethylapigenin-6-C-(2"-O- $\alpha$-L-rhamnopyranosyl)- $\beta$-L-fucopyranoside, $7-\mathrm{O}-$ methyl- 
apigenin $6-\mathrm{C}-(4 "-\mathrm{O}-\alpha-\mathrm{L}$ rhamnopyranosyl)- $\beta$-L-fucopyranoside, and 2 '- C$\beta$-fucopyr-anosyl 3',4,4' trihydroxydihydrochalcone- 5' - O - $\alpha$ arabinofuranosid ${ }^{[13]}$. Kurian et al. (2018) conducted phytochemical screening and isolation and identification of flavonoids from the methanol extract of $A$. bilimbi fruit. The results of phytochemical screening showed that the extract was positive for alkaloids, flavonoids, triterpenoids, tannins, phenolic compounds, and amino acids. The results of the isolation and identification of flavonoids showed that the fruit of A.bilimbi contained dihydromyricetin, namely $(2 \mathrm{R}$, 3R) - 3, 5, 7-trihydroxy - 2 - (3, 4, 5trihydroxyphenyl) 2,3-dihydrochromen -4one with molecular formula $\mathrm{C}_{15} \mathrm{H}_{12} \mathrm{O}_{8}{ }^{[14]}$. Abraham (2016) identified 20 compounds contained in the methanol extract of A.bilimbi fruit using the LC-MS method. These chemical ingredients are umbelliferone, salicylic acid, transresveratrol, dihydromyricetin, methyl salicylate, boswellic acid, eriocitrin, hydroxy aristolochic acid, benzyl cinnamate, cinnnamaldehyde, hydroxy citric acid lactone, benzyl alcohol, phenyethyll amine, leaf alcohol, caffeolmalic acid, ascorbic acid, tartaric acid, citric acid, xylose, and tyrosine ${ }^{[15]}$.

\section{Antibacterial Activities In Vitro With Diffusion Method}

Averrhoa bilimbi which has been studied in vitro by diffusion method can inhibit pathogenic bacteria, both Grampositive and Gram-negative bacteria. The ethanol extract of $A$. bilimbi leaves had activity against several bacteria such as Bacillus cereus, Staphylococcus aureus, Pseudomonas sp., Enterobacter sp, Escherichia coli, Shigella dysentriae, and Propionibacterium acnes $[9,16,17,18]$. It is known that $70 \%$ ethanol extract of $A$. bilimbi leaves gives better results in the inhibition of $B$. cereus, $S$. aureus, Pseudomonas sp., and Enterobacter sp. compared to ethyl acetate extract. Best inhibition against $B$. cereus and Enterobacter sp. was given by ethanol extract of $70 \%$ A. bilimbi leaves with a concentration of $20 \%(\phi 11.43$ and $\phi 6.32$ $\mathrm{mm})$. While the best inhibition against $S$. aureus and Pseudomonas sp. was given by ethanol extract of $70 \%$ A. bilimbi leaves with a concentration of $25 \% \quad(\phi 8.8$ and $\phi 4.94 \mathrm{~mm})^{[16]}$. The $70 \%$ ethanol extract of A. bilimbi leaves studied by Pendit et al. (2016) gave the best test results for $S$. aureus and E. coli bacteria at $100 \%$ extract concentrations $(\phi 13.13 \text { and } \phi 8.63 \mathrm{~mm})^{[17]}$. The $70 \%$ ethanol extract also had antibacterial activity against $S$. dysentriae with the best concentration of $100 \%$ $(\phi 14.47 \mathrm{~mm})^{[18]}$. The $70 \%$ ethanol extract of A. bilimbi leaves formulated as a face toner is known to have antibacterial activity against $P$. acnes by providing the best inhibitory response at a concentration of $10 \%(\phi 24.7 \mathrm{~mm})^{[9]}$.

The ethanol extract of $A$. bilimbi leaves had antibacterial activity against Salmonella typhi by providing a growth inhibition zone at a concentration of 0.3 ; 0.4 ; and $0.5 \mathrm{~g} / \mathrm{mL}$ with an inhibitory diameter of $20.75 ; 21.88 ; 22.88 \mathrm{~mm}^{[8]}$. The $95 \%$ ethanol extract of $A$. bilimbi leaves with a concentration of $200 \mu \mathrm{g} /$ disc gave a moderate inhibitory response to the bacteria Bacillus megaterium, S. typhi, and Vibrio cholerae with an inhibitory diameter of 14.67; 13.33; and $13.67 \mathrm{~mm}$. The extract also gave a low inhibitory response to $B$. cereus; E. coli; Pseudomonas aeruginosa; Salmonella paratyphi; and S. dysentriae with an inhibitory diameter of $12.0 ; 11.0$; 10.33; 10.0; and 10.67 respectively ${ }^{[1]}$. The $96 \%$ ethanol extract of $A$. bilimbi leaves gave the highest resistance response to Pseudomonas fluoroscens with a concentration of $85 \mathrm{ppm}(\phi 5.79 \mathrm{~mm})^{[7]}$.

The ethanol extract of $A$. bilimbi fruit was known to have activity against $P$. aeruginosa (ATCC 15692) with an inhibitory diameter of $3 \mathrm{~mm}^{[19]}$. Meanwhile, the ethanol extract of $A$. bilimbi fruit studied by Dewi et al. (2019) gave the best 
antibacterial activity against Streptococcus pyogenes at a concentration of $80 \%(\phi 30.99$ $\mathrm{mm})^{[20]}$. Comparatively, the chloroform extract of $A$. bilimbi fruit concentration of $150 \mathrm{mg} /$ disc has a strong antibacterial effect against B. subtilis; S. aureus; and Serratia marcescens with inhibition diameter above $20 \mathrm{~mm}$, and moderate antibacterial effect against Klebsiella pneumonia with inhibition diameter range $11-20 \mathrm{~mm}^{[15]}$.

The methanol extract of the fruit of $A$. bilimbi with a concentration of $150 \mathrm{mg} / \mathrm{disc}$ had a moderate antibacterial effect on $B$. subtilis; S. aureus; and Klebsiella pneumonia with an inhibitory diameter range of $11-20 \mathrm{~mm}$, as well as a low antibacterial effect against Serratia marcescens with an inhibition zone below $11 \mathrm{~mm}{ }^{[15]}$. Methanol extract $80 \%$ of $A$. bilimbi fruit gave an inhibitory response to B. subtilis by $7 \mathrm{~mm}^{[21]}$.

The extract of $A$. bilimbi fruit was also known to have the best antibacterial activity against $P$. acnes at a concentration of $100 \%$ $(\phi 21 \mathrm{~mm})^{[22]}$. Extracts of juice, stew, and fruit infusion of $A$. bilimbi with a concentration of $10 \%$ gave an inhibitory response to $P$. acnes with an average diameter of the inhibition zone of each extract, respectively $11 ; 10$; and $10.6 \mathrm{~mm}$ [23].

Starfruit fruit solution provided the highest antibacterial activity against $E$. coli and Salmonella sp. at a concentration of $30 \%$ with inhibition zones of 6.8 and 5.07 $\mathrm{mm}$, respectively ${ }^{[24]}$. The water extract of A. bilimbi fruit at various levels of maturity, namely young, mature, and ripe fruit had antibacterial activity against $B$. cereus, $S$. aureus, $P$. aeruginosa, E. coli, and Salmonella spp. The best inhibitory response to $B$. cereus and $S$. aureus was given by mature fruit extract with inhibition zones of 9.7 and $12.3 \mathrm{~mm}$, respectively. Meanwhile, the best inhibitory response to P. aeruginosa, E. coli, and Salmonella spp was given by young fruit extract with 9 inhibition zones; 10.3 ; and $12 \mathrm{~mm}^{[2]}$.
The ethyl acetate extract of $A$. bilimbi fruit and leaves could inhibit Salmonella typhimurium at the best extract concentration of $10 \%$ with an inhibition diameter of 9.5 and $3.33 \mathrm{~mm}$, respectively ${ }^{[25]}$. The extract of the ethanol-water mixture (7: 3) of $A$. bilimbi leaves by giving the higher concentration gives a bigger zone of inhibition. The extract provided the best antibacterial activity against $P$. acnes at a concentration of $225 \mathrm{mg} / \mathrm{mL}$ with an inhibition zone of $12.52 \mathrm{~mm}^{[26]}$.

\section{Antibacterial Activities In Vitro With Dilution Method}

In vitro studies of antibacterial activity can also be carried out by the dilution method to determine the minimum inhibitory concentration (MIC) and the minimum bactericidal concentration (MBC). The following are the results of several studies on the antibacterial activity of $A$. bilimbi using this method. The $70 \%$ ethanol extract of $A$. bilimbi leaves had antibacterial activity against $B$. cereus, $S$. aureus, Pseudomonas sp., and Enterobacter sp. with MIC/MBC values for each bacteria of $0.25 \% / 1 \% ; 0.75 \% / 2.99 \% ; 0.85 \% / 3.39 \%$; $0.56 \% / 2.24(\mathrm{v} / \mathrm{v})^{[16]}$. The ethanol extract of $70 \%$ A. bilimbi leaves also had antibacterial activity against $S$. dysentriae with a MIC value of $25 \%{ }^{[18]}$. The MIC value given by the ethanol extract of $A$. bilimbi leaves against $B$. megaterium was $62.50 \mathrm{ppm}$, while the other bacteria were $B$. megaterium; S. typhi; V. cholerae; $B$. cereus; E. coli; P. aeruginosa; $S$. paratyphi; and $S$. dysentriae has a MIC above 100 ppm [1].

The $96 \%$ ethanol extract of $A$. bilimbi leaves had a MIC value of 5 ppm against Pseudomonas fluorescens ${ }^{[7]}$. The extract of A. bilimbi leaves tested by Azizah (2017) had a MIC value of $80 \%$ against $E$. coli ${ }^{[27]}$. Studies on the antibacterial activity of the water extract of young and mature $A$. bilimbi fruit showed that the extract from the young fruit was more effective against $E$. coli with a MIC value of $0.125 \mathrm{~g} / \mathrm{mL}$, 
while the extract from the mature fruit was more effective against $S$. aureus with a MIC value of $0.125 \mathrm{~g} / \mathrm{mL}^{[2]}$.

The $80 \%$ methanol extract of $A$. bilimbi fruit and leaves had a MIC value of 1.6 $\mathrm{mg} / \mathrm{mL}$ against Mycobacterium tuberculosi ${ }^{[28]}$. In another study, $80 \%$ methanol extract of A. bilimbi fruit had a MIC value of 5 $\mathrm{mg} / \mathrm{mL}$ against $B$. subtilis ${ }^{[21]}$. The ethyl acetate extract of $A$. bilimbi fruit and leaves has a MIC value of $60 \%$ against Salmonella thypymurium ${ }^{[25]}$. The ethanol-water extract mixture $(7: 3)$ of $A$. bilimbi leaves gave a MIC value of $100 \mathrm{mg} / \mathrm{mL}$ against $P$. acnes [26]

\section{Antibacterial Activity Mechanism}

Averrhoa bilimbi has been shown to have antibacterial activity in vitro. The antibacterial activity is thought to be obtained from several chemical compounds contained in A. bilimibi. Several chemical compounds that have been identified and have antibacterial activity include flavonoids, alkaloids, glycosides, saponins, tannins, triterpenoids, and steroids. The chemical compounds that have been identified can work as antibacterial agents through different mechanisms. Flavonoids and tannins are thought to interact nonspecifically and affect on cell wall biosynthesis ${ }^{[29]}$. Alkaloids and glycosides in their role as antibacterial work by disrupting the integrity of the peptidoglycan components of bacterial cells; saponins increase the permeability of bacterial cell membranes; tannins interfere with bacterial cell metabolism with complex formation; phenolic denatures bacterial cell proteins; triterpenoids reduce the permeability of the bacterial cell wall so that the bacteria are deprived of nutrients; and steroids by mechanisms that cause bacterial liposomes to leak ${ }^{[8]}$. Dihydromyricetin caused morphological changes and damages the membrane of bacterial cells. This may be due to lysis of the cell wall, the release of intracellular components, and inhibits the tricarboxylic acid cycle which is one of the stage of cellular respiration in bacteria ${ }^{[30]}$.

\section{Toxicity Study}

Toxicity testing is very important to do in ensuring the safety of the extract to be used as medicine. So that the risk due to exposure to the extract in humans can be avoided. Based on the acute and subchronic toxicity tests conducted by Othman et al. (2014), $80 \%$ ethanol extract of Averrhoa bilimbi fruit given orally to female Sprague Dawley Rats gave $\mathrm{LD}_{50}$ values above $5,000 \mathrm{mg} / \mathrm{kg} \mathrm{BW}$. In this test, there was no death and changes in the test animal's behaviour ${ }^{[31]}$. The results of a study conducted by Wulandari (2017) also showed that the standardized extract of $A$. bilimbi leaves containing $5.24 \% \quad(\mathrm{w} / \mathrm{w})$ quercetin had an $\mathrm{LD}_{50}$ value above 5.400 $\mathrm{mg} / \mathrm{kg} \mathrm{BW}{ }^{[32]}$. Based on the BPOM acute toxicity criteria, an $\mathrm{LD}_{50}$ above $5.000 \mathrm{mg} / \mathrm{kg}$ is defined as practically non-toxic ${ }^{[33]}$. The results of a short sub-chronic toxicity test of $80 \%$ ethanol extract of $A$. bilimbi fruit given orally for 28 days on male and female Sprague Dawley rats showed that there were no deaths, toxic symptoms, and changes in body weight at all test doses, namely $125 \mathrm{mg} / \mathrm{kg} \mathrm{BW}, 250 \mathrm{mg} / \mathrm{kg} \mathrm{BW}$, and $500 \mathrm{mg} / \mathrm{kg} \mathrm{BW}^{[31]}$.

The toxicity test of $70 \%$ ethanol extract of A. bilimbi leaves using the brine shrimp lethality test (BSLT) method on shrimp larvae (Artemia Salina L.) had a moderate toxic effect with an $\mathrm{LC}_{50}$ value of 367.28 $\mu \mathrm{g} / \mathrm{mL}^{[34]}$. Meanwhile, the ethanol extract of $95 \%$ A. bilimbi leaves using the brine shrimp lethality bioassay method in shrimp larvae gave $\mathrm{LC}_{50}$ and $\mathrm{LC}_{90}$ values of 5,81 and $10,28 \mu \mathrm{g} / \mathrm{mL}^{[1]}$.

\section{CONCLUSION}

Averrhoa bilimbi, both the fruit and the leaves, are known to have antibacterial activities against several Gram-positive bacteria and Gram-negative bacteria. Based on the testing of several A. bilimbi extracts, Gram-positive bacteria that can be inhibited 
include $B$. cereus, $B$. megaterium, $B$. subtilis, $M$. tuberculosis, $P$. acnes, $S$. aureus, and $S$. pyogenes. Meanwhile, Gram-negative bacteria that can be inhibited by A.bilimbi extract include $E$. coli, $K$. pneumonia, $P$. aeruginosa, Pseudomonas fluorescens, Salmonella spp., $S$. typhi, Salmonella paratyphi, $S$. typhimurium, Serratia marcescens, $S$. dysenteriae, and $V$. cholerae. The antibacterial activity is associated with the chemical content of A. bilimbi. Based on the results of acute and sub-chronic toxicity tests, it is known that A. bilimbi extract is safe to use.

\section{CONFLICT OF INTEREST}

There was no conflict of interest in the preparation of this article. This article was written independently without any third party involvement.

\section{ACKNOWLEDGMENT}

The preparation of this article was supported by all parties from the Department of Pharmacy, Faculty of Mathematics and Natural Sciences, Udayana University.

\section{REFERENCES}

1. Karon B, Ibrahim M, Mahmood A, Huq AKMM, Chowdhury MMU, Hossain MdA, et al. Preliminary Antimicrobial, Cytotoxic and Chemical Investigations of Averrhoa bilimbi Linn. and Zizyphus mauritiana Lam. Bangladesh Pharmaceutical Journal. 2011; 14(2): 127-131.

2. Mokhtar SI, Aziz NAA. Antimicrobial Properties of Averrhoa bilimbi Extracts at Different Maturity Stages. Journal of Medical Microbiology \& Diagnosis. 2016; 5(3): 1-3.

3. Depkes RI. Materia Medika Indonesia. Jilid V. Jakarta: Departemen Kesehatan Republik Indonesia; 1989. pp. 92.

4. Purwaningsih E. Multiguna Belimbing Wuluh. Bekasi: Ganeca Exact; 2007. pp. 26.
5. Slipranata M, Lestari FB, Sandi NA, Salasia SIO. Potensi Ekstrak Daun Sage (Salvia officinalis. L) sebagai anti-Streptococcus suis Penyebab Zoonotik Meningitis. Jurnal Sain Veteriner. 2016; 34 (2): 198-202.

6. Karadi RV, Arpan S, Pranav P, Parvez A. Antimicrobial Activities of Musa paradisiaca and Cocos nucifera. International. Journal of Research in Pharmaceutical and Biomedical Sciences. 2011; 2: 264-267.

7. Andayani S, Suprastyania H, Rahmawati ED. Pengaruh Pemberian Ekstrak Kasar Daun Belimbing Wuluh (Averrhoa bilimbi L.) Terhadap Daya Hambat Bakteri Pseudomonas fluorescens Secara In Vitro. Journal of Fisheries and Marine Research. 2019; 3(3): 301-307.

8. Hasdiana F, Kuswarini S, Koendhari EB. Antibacterial Activity of Belimbing Wuluh (Averrhoa Bilimbi Linn.) Extract on Salmonella Typhi Growth. Folia Medica Indonesiana. 2012; 48(4): 144-149.

9. Hasanah N, Novian DR. Daya Hambat Ekstrak Daun Belimbing Wuluh (Averrhoa bilimbi L.) Terhadap Bakteri Penyebab Jerawat (Propionibacterium acnes). Jurnal Ilmiah Farmasi. 2020; 9(1): 46-53.

10. Yan SW, Ramasamy R, Alitheen NBM, Rahmat A. A Comparative Assessment of Nutritional Composition, Total Phenolic, Total Flavonoid, Antioxidant Capacity, and Antioxidant Vitamins of Two Types of Malaysian Underutilized Fruits (Averrhoa bilimbi and Averrhoa carambola). International Journal of Food Properties. 2013; 16(6): 12311244.

11. Patil AG, Koli SP, Patil DA. Pharmcognostical Standardization and HPTLC Fingerprint of Averrhoa bilimbi (L.) Fruits. Journal of Pharmacy Research. 2013; 6(2013): 145-150. 
12. Bhasker B, Shantaram M. Morphological and Biochemical Characteristics of Averrhoa fruits. International Journal of Pharmaceutical, Chemical and Biological Sciences. 2013; 3(3): 924928.

13. Auw L, Subehan, Sukrasno, Kadotaa S, Tezuka Y. Constituents of Indonesian Medicinal Plant Averrhoa bilimbi and Their Cytochrome P450 3A4 and 2D6 Inhibitory Activities. Natural Product Communications. 2014; 10 (1): 57-62.

14. Kurian AJ, Geetha G, Thavamani BS. Isolation and Characterisation of an Isolated Flavonoid from Averrhoa bilimbi. Asian Journal of Chemical Sciences. 2018; 5(1): 1-8.

15. Abraham CM. Antibacterial Effects of Averrhoa Bilimbi L. Fruit Extracts. International Research Journalof Biological Sciences. 2016; 5(8): 72-74.

16. Soedirga LC, Parhusip AJ. Aktivitas Antibakteri Ekstrak Daun Belimbing Wuluh (Averrhoa bilimbi L.) Terhadap Bakteri Patogen Pangan. Jurnal Sains dan Teknologi. 2019; 3(2): 27-34.

17. Pendit PACD, Zubaidah E, Sriherfyna FH. Karakteristik Fisik-Kimia dan Aktivitas Antibakteri Ekstrak Daun Belimbing Wuluh (Averrhoa bilimbi L.). Jurnal Pangan dan Agroindustri. 2016; 4(1): 400-409.

18. Panjaitan RS, Kadiwijati LR, Seto D, Hengky. Uji Aktivitas Antibakteri Ekstrak Etanol $70 \%$ dari Daun Belimbing Wuluh (Averrhoa blimbi L.) Terhadap Bakteri Shigella dysenteriae. Indonesia Natural Research Pharmaceutical Journal. 2017; 2(1): 81-90.

19. Alva PP, Suresha S, Gururaj MP, Premanath R. Evaluation of antiquorum sensing activity of indigenous dietary plants against Pseudomonas aeruginosa. 2019; 30(2019): 1-7.

20. Dewi P, Ratih GA, Burhannuddin, Sudarmanto IG. In vitro Inhibitory Activity of Ethanolic Fruit Extract from Averrhoa bilimbi L. Against Streptococcus pyogenes Bacteria. Health Nations. 2019; 3(1): 13-17.

21. Sundis MA, Baharuddin S. Inhibitory Activity of Plant Extracts Against Microbes Isolated from Sick Building. Health and the Environment Journal. 2012; 3(2): 61-73.

22. Rusdiaman. Uji Daya Hambat Perasan Buah Belimbing Wuluh (Averrhoa bilimbi L) Terhadap Pertumbuhan Propionibacterium acnes. Media Farmasi. 2018; XIV(1): 153-157.

23. Arisanty, Dewi RP. Efektivitas Ekstrak Air Buah Belimbing Wuluh (Averrhoa bilimbi) Terhadap Pertumbuhan Propionibacterium acnes. Media Farmasi. 2018; XV(2): 66-71.

24. Wijayanti DA, Sjofjan O, dan Djunaidi IH. Pengaruh Variasi Konsentrasi Larutan Belimbing Wuluh (Averrhoa bilimbi) Terhadap Uji Aktivitas Antimikroba Secara In Vitro. Jurnal Ilmu-Ilmu Peternakan. 2019; 29(1): 9 14.

25. Suliani A, Latief M, dan Rahmi SL. Aktivitas Antimikroba Ekstrak Etil Asetat Buah dan Daun Belimbing Wuluh (Averrhoa bilimbi Linn) Terhadap Mikroba Salmonella tyhipimurium dan Aspergillus flavus. Chempublish Journal. 2016; 1(2): 3241.

26. Afifi R, Erlin E, Rachmawati J. Uji Anti Bakteri Ekstrak Daun Belimbing Wuluh (Averrhoa bilimbi L.) Terhadap Zona Hambat Bakteri Jerawat Propionibacterium acnes Secara In Vitro. Jurnal Pendidikan dan Biologi. 2018; 10(1): 10-17.

27. Azizah F. Pengaruh Perasan Daun Belimbing Wuluh (Averrhoa bilimbi) Terhadap Pertumbuhan Bakteri Escherichia coli Patogen. The Journal of Muhammadiyah Medical Laboratory Technologist. 2017; 1(2): 47-54.

28. Mohamad S, Zin NM, Wahab HA, Ibrahim P, Sulaiman SF, Zahariluddin 
ASM, et al. Antituberculosis Potential of Some Ethnobotanically Selected Malaysian Plants. Journal of Ethnopharmacology. 2011; 133(2011): 1021-1026.

29. Do Nascimento PGG, Lemos TLG, Bizerra AMC, Arriaga ÂMC, Ferreira DA, Santiago GMP, et al. Antibacterial and Antioxidant Activities of Ursolic Acid and Derivates. Molecule. 2014; 19(1):1317 - 1327

30. Xiao X-N, Wang F, Yuan Y-T, Liu J, Liu Y-Z, and Yi X. Antibacterial Activity and Mode of Action of Dihydromyricetin from Ampelopsis grossedentata Leaves against FoodBorne Bacteria. Molecules. 2019; 24(15): 2831

31. Othman FA, Hashim N, Abdullah N, Hamid AA, Abdullah MFF, Noor ZM, et al. Toxicity Evaluation of A. Bilimbi L. Fruit Extract on Haematological and Histopathological Analysis in Animal Model. International Journal of Pharmaceutical Sciences Review and Research. 2014; 26(2): 39-43.

32. Wulandari WP. Uji Toksisitas Ekstrak Daun Belimbing Wuluh (Averrhoa bilimbi L.) Terstandar Kuersetin pada Mencit Putih (Mus msuculus). Thesis. Universitas Airlangga; 2017.

33. BPOM. Peraturan Kepala Badan Pengawas Obat dan Makanan Republik Indonesia Nomor 7 Tahun 2014 Tentang Pedoman Uji Toksisitas Nonklinik Secara In Vivo. Jakarta: Badan Pengawas Obat dan Makanan; 2014.

34. Rahimah S, Maryam FBA, Limbong BA. The Toxicity Test of Ethanol Extract of Leaves Averrhoa bilimbi L. Using Brine Shrimp Lethality Test (BSLT). Journal of Pharmaceutical and Medicinal Sciences. 2019; 4(1): 10-14. 